\title{
INFORMATION SEEKING BEHAVIOUR OF LIBRARY USERS IN DEVANGA ARTS COLLEGE AT ARUPPUKOTTAI : A SURVEY
}

\author{
Dr. M. Rajavel \\ Librarian \\ Devanga Arts College, Aruppukottai \\ E-mail:rajlibdac@gmail.com
}

\section{Manuscript Info Abstract}

\section{Manuscript History}

Received: 01 February 2021

Final Accepted: 22 March 2021

Published: 10 April 2021

Online Published: May 2021

DOI: http:/ /dx.doi.org/10.35337/EIJLITR.2021.1501

(C) Dr. M. Rajavel The Author. This is an open access article under the terms of the Creative Commons Attribution License 4.0, which allows use, distribution and reproduction in any medium, provided the original work is properly cited.

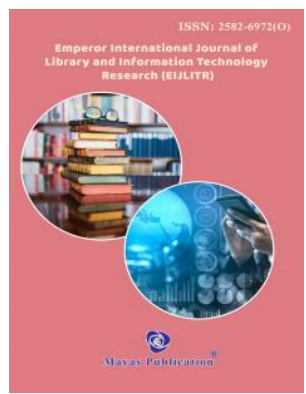

The current assessment was endeavored in order to know the circumstance with information searching for lead of Devanga Arts school library customers, The respondents of the flow examination are basically drawn from the eight picked course of our school. Audit methodology has been embraced by the trained professionals, which contains association of overview, view of the individuals, and meeting of a segment of the individuals for knowing the circumstance with Information Seeking Behavior of the respondents in respect of library visit, tendency of scrutinizing materials identifying with their educational and assessment works out. Oneself arranged overview has been circled among the selfassertively picked tests. The models include UG understudies and Staff. The finished off overviews have been accumulated from the respondents for the data assessment and understandings. In view of finished off review the data has been. For data assessment rate method has been gotten.

Keywords:: Information searching for lead; Devanga Arts school library; Users, formal resources; Informal resources.

\section{INTRODUCTION}

Information is the major material for the powerful association. In the current day, information is seen as a resource, a thing, and likewise a need. Notwithstanding, today everybody is managing an exceptional issue in light of information impact. On account of this information impact or information pollution people are overwhelmed about the information need, information access and information sources. Again information access changes starting with one individual then onto the next as shown by their 
prerequisites. As such, information searching for is a kind of correspondence lead, which may be affected by various factors, singular working environment.

Library expects a crucial part during the time spent information pursuing. In light of resources splitting between the libraries with electronic consortia, the supposition and lead of library customers is in like manner changing bit by bit. Without a doubt, for certain customers of the library, permission to coordinated information resources, instead of genuine access, is the supported technique for use in this current circumstance. As such the information searching for lead is used here to fuse all activities differentiating information pursuing, information gathering, recuperating and correspondence practices acted in the library.

\section{OBJECTIVES}

The objectives of the assessment are according to the accompanying:

$>\quad \square$ To find the Library Visit Pattern of College Library User

$>\quad \square$ To find the Visit to various Libraries by the school Library Users

$>\quad \square$ To find the Types of Libraries Visited by College Library Users/Respondent

$>\quad \square$ To find the Ranking of Purpose of Seeking Information by Respondents

$>\quad \square$ To find the Search Strategies Adopted by the Respondents for Seeking Desired

\section{Information}

$>$ To find the Ranking of the loved of getting materials/resources

$>$ To find the Suggestion Improve Library Services and Usage from the eight picked course of Devanga Arts school in Aruppukottai.

\section{III.SCOPE OF THE STUDY}

The assessment is endeavored in the understudies orchestrated in the eight picked Course of Devanga Arts College at Aruppukottai. There are Two hundred understudies in Devanga Arts College at Aruppukottai.

\section{PERIOD OF STUDY}

The examination is embraced from January 2021 to March 2021 for a Period of Three months.

\section{REVIEW OF LITERATURE}

According to Kakai, et al., (2004) have portrayed information searching for direct as an individual's way and method of get-together and sourcing for information for singular use, data reviving, and development.[4] Information-pursuing behavior of understudies, researchers, and instructors has been the point of convergence of enquiry for a serious long time. From the outset, regardless, customer ponders were driven in a general sense to evaluate library collections.

These were followed by examinations of the investigation penchants for individuals or get-togethers that would incite the arrangement of appropriate information structures and organizations. In mid 1980s, the middle moved to exhaustive approaches to manage information searching for lead. According to Line (2000), new examinations of information customers and their prerequisites are impressively more key in the age of the Internet. Researchers like Callison (1997), Devadason and Pratap (1997), and Ellis (1993) have explored quantitative and emotional ways of thinking for customer analyzes . 


\section{RESEARCH METHODOLOGY}

Information searching for direct of Library customers in Devanga Arts College at Aruppukottai. The characterized discretionary inspecting procedure was used to accumulate the data from the general population. The current examination joins 200 respondents using Internet drawn from eight Department library customers of Devanga Arts College. The overview was passed on the respondents as per the need of the objectives of the current assessment. The survey has been scattered to library customers include school understudies and staff. To each Department 25 instances of study has flowed to the respondents. The finished off review has been assembled from the respondents for the data assessment and comprehension.

TABLE 1

DISTRIBUTION OF QUESTIONNAIRE AND RESPONSES RECEIVED (N=200)

\begin{tabular}{|c|l|c|c|}
\hline S.No & \multicolumn{1}{|c|}{ Questionnaire } & No. of Respondents & Percentage (\%) \\
\hline 1 & Questionnaire Received & 160 & $80.00 \%$ \\
\hline 2 & Questionnaire Not Received & 40 & $20.00 \%$ \\
\hline 3 & Total Distributed & 200 & $100.00 \%$ \\
\hline
\end{tabular}

200 surveys have been dispersed among the school library customers of eight picked course in Devanga Arts College. Out of which 160 ( $80.00 \%$ ) respondents have returned the finished off survey however 40 ( $20.00 \%)$ respondents have not returned the review. Subsequently the response rate $80.00 \%$ is a fair response.

TABLE 2

SUBJECT WISE DISTRIBUTION AND RECEIPT OF QUESTIONNAIRE (N=160)

\begin{tabular}{|c|l|c|c|c|}
\hline S.No & $\begin{array}{c}\text { Name of the Subject } \\
\text { Course }\end{array}$ & $\begin{array}{c}\text { Questionnaire distributed to each } \\
\text { Subject }\end{array}$ & $\begin{array}{c}\text { Responsed } \\
\text { received }\end{array}$ & $\begin{array}{c}\text { percent } \\
\mathbf{( \% )}\end{array}$ \\
\hline 1 & B.A (Tamil) & 25 & 18 & $11.25 \%$ \\
\hline 2 & B.A (English) & 25 & 19 & $11.87 \%$ \\
\hline 3 & B.A (History) & 25 & 18 & $11.25 \%$ \\
\hline 4 & B.A (Economics) & 25 & 19 & $11.87 \%$ \\
\hline 5 & B.Sc (Maths) & 25 & 22 & $13.75 \%$ \\
\hline 6 & B.Sc (Physics) & 25 & 23 & $14.37 \%$ \\
\hline 7 & B.Sc (Chemistry) & 25 & 21 & $13.12 \%$ \\
\hline 8 & B.Com & 25 & 20 & $12.50 \%$ \\
\hline & Total & 200 & 160 & $99.98 \%$ \\
\hline
\end{tabular}

In the current assessment 200 respondents from eight divisions in Devanga Arts school. It was picked to pass on 25 studies to each Department in our school. $163(65 \%)$ survey got from the respondents dispersed across the eight office in our school. It is obvious from the Table- 2 that out of 160 respondents the best responses $(23=14.37 \%)$ was gotten from the respondents of B.Sc (Physics) division in our school. which is followed by $22(13.75 \%)$ respondents from B.Sc (Maths) division and 21 (13.12\%) respondents from B.Sc (Chemistry) office and 20 (12.50 \%) respondents from B.Com office 19 (11.87\%) respondents are two workplaces from B.A (Economics),B.A (English) and 18 (11.25\%) respondents are two workplaces from B.A (Tamil),B.A (History) in our school.

TABLE 3

GENDER- WISE DISTRIBUTION OF COLLEGE LIBRARY USERS ( $\mathbf{N}=160)$

\begin{tabular}{|c|l|c|c|}
\hline S.No & Gender & Number of Respondent & Percentage (\%) \\
\hline 1 & Male & 65 & $40.62 \%$ \\
\hline 2 & Female & 95 & $59.37 \%$ \\
\hline 3 & Total & 160 & $99.99 \%$ \\
\hline
\end{tabular}


From the Table 3, clearly out of 160 respondents, 95 (59.37\%,) of respondents are female, and $65(40.62 \%)$ respondents are male. Most noteworthy respondents for library customers from female sexual direction in our school.

TABLE 4

AGE- WISE DISTRIBUTION OF RESPONDENTS / COLLEGE LIBRARY USERS (N=160)

\begin{tabular}{|c|l|c|c|}
\hline S.No & Age Group & No. of Respondents & Percent (\%) \\
\hline 1 & $16-25$ & 136 & $85.00 \%$ \\
\hline 2 & $26-40$ & 6 & $3.75 \%$ \\
\hline 3 & $41-50$ & 10 & $6.25 \%$ \\
\hline 4 & 51 and above & 8 & $5.00 \%$ \\
\hline & Total & 120 & $100.00 \%$ \\
\hline
\end{tabular}

The age-wise appointment of 160 respondents from Library Users which reveals that $136(85.00 \%)$ respondents have a spot with 16-25 years age bundle which is followed by $6(3.75 \%)$ respondents who have a spot with 26-40years age pack, while $10(6.25 \%)$ respondents have a spot with $41-50$ years age social affair and $8(5.00 \%)$ respondents have a spot with 51and Above years age pack. Most limit respondents for age-wise library customers from long haul age bundle in our school.

TABLE 5

CATEGORY WISE DISTRIBUTION OF COLLEGE LIBRARY USERS $(\mathbf{N}=\mathbf{1 6 0})$

\begin{tabular}{|c|l|c|c|}
\hline S.No & Type & No. of Respondents & Percentage (\%) \\
\hline 1 & Student & 136 & $85.0 \%$ \\
\hline 2 & Staff & 24 & $15.0 \%$ \\
\hline 3 & Total & 160 & $100.0 \%$ \\
\hline
\end{tabular}

Class astute appointment of 160 respondents from library customers , $136(85.00 \%)$ have a spot with understudies characterization, which is followed by staff people $24(15.00 \%)$ from our school. Most noteworthy respondents for Category clever from understudies arrangement in our school.

TABLE 6

LIBRARY VISIT PATTERN OF COLLEGE LIBRARY USERS $(\mathrm{N}=160)$

\begin{tabular}{|c|l|c|c|}
\hline S.No & Library Visit Pattern & No. of Respondents & Percent (\%) \\
\hline 1 & Daily & 70 & $43.75 \%$ \\
\hline 2 & Weekly & 43 & $26.87 \%$ \\
\hline 3 & Monthly & 20 & $12.5 \%$ \\
\hline 4 & Free hours & 15 & $9.37 \%$ \\
\hline 5 & Not Regularly & 12 & $7.5 \%$ \\
\hline 6 & Total & 160 & $99.99 \%$ \\
\hline
\end{tabular}

The repeat of library visits by library customers are saw the table No:6 which shows the library visits illustration of the school library customers which exhibits that most of the respondents $70(43.75 \%)$ visit library on step by step . which is followed by $43(26.87 \%)$ respondents who visit library on step by step, $20(12.5 \%)$ visit library on month to month $15(9.37 \%)$ respondents visit library on free hours, $12(7.5 \%)$ visit library on not regularly. Most noteworthy respondents for library visits by customers from step by step library visit in our school.

TABLE 7

VISIT TO OTHER LIBRARIES BY THE COLLEGE LIBRARY USERS $(\mathbf{N}=\mathbf{1 6 0})$

\begin{tabular}{|c|l|c|c|}
\hline S.No & Visit to other Libraries & No. of Respondents & Percent (\%) \\
\hline 1 & Yes & 110 & $68.75 \%$ \\
\hline 2 & No & 50 & $31.25 \%$ \\
\hline 3 & Total & 160 & $100.0 \%$ \\
\hline
\end{tabular}


To understand the library visit illustration of the respondents other than school library, the respondents were drawn closer to teach their visit to various libraries. The audit finding as shown in Table No: 7 shows that simply $110(68.75 \%)$ respondents visited various libraries close by their school library .50 $(31.25 \%)$ respondents don't think about the library organizations being given by various libraries.

TABLE 8

TYPES OF LIBRARIES VISITED BY COLLEGE LIBRARY USERS $(\mathbf{N = 1 1 0 )}$

\begin{tabular}{|c|l|c|c|}
\hline S.No & Types of Libraries Visited & No. of Respondents & Percent (\%) \\
\hline 1 & Public Libraries & 45 & $40.90 \%$ \\
\hline 2 & Private Libraries & 30 & $27.27 \%$ \\
\hline 3 & Academic Libraries & 25 & $22.72 \%$ \\
\hline 4 & Special Libraries & 10 & $9.09 \%$ \\
\hline 5 & Total & 110 & $99.98 \%$ \\
\hline
\end{tabular}

Table No:8 shows that out of 110 respondents who have visited libraries other than school library, most of them $45(40.90 \%)$ visited Public libraries, while 30 (27.27\%) visited privare libraries, and $25(22.72 \%)$ respondents visited Academic libraries and 10 (9.09\%) visited unprecedented libraries . Most of the respondents are used public libraries.

TABLE 9

RANKING OF PURPOSE OF SEEKING INFORMATION BY USERS (N=160)

\begin{tabular}{|c|l|c|c|}
\hline S.No & Purpose of library Visit & $\begin{array}{c}\text { Frequency } \\
\text { ( Percent }\end{array}$ & Rank \\
\hline 1 & Newspaper & $120(75.0 \%)$ & 1 \\
\hline 2 & Up-to-date on the subject & $95(59.37 \%)$ & 2 \\
\hline 3 & Competitive Examinations & $90(56.25 \%)$ & 3 \\
\hline 4 & Career Development & $75(46.87 \%)$ & 4 \\
\hline 5 & Academic Assignmen & $70(43.75 \%)$ & 5 \\
\hline 6 & Magazines & $65(40.62 \%)$ & 6 \\
\hline 7 & Research Journal & $40(25.0 \%)$ & 7 \\
\hline 8 & Others & $20(12.5 \%)$ & 8 \\
\hline
\end{tabular}

The investigation results as shown in Table-9 shows that a large portion of the respondent $120(75.0 \%)$ visit the library to scrutinizing Newspaper of premium put from the start position and followed by Up-to date in regards to the matter $95(59.37 \%)$ set at the subsequent position and followed by Competitive Examinations $90(56.25 \%)$ put at the third position and followed by means of Career Development 75 (46.87\%) put at the fourth position and followed by Academic Assignment 70 (43.75\%) set at the fifth position and followed by Magazines $65(40.62 \%)$ put at the 6th position and followed by Research Journal $40(25.0 \%)$ set at the seventh position and followed by Others $20(12.5 \%)$ set at the eighth position . Most limit respondents for library searching for information is examining News paper in our school.

TABLE 10

SEARCH STRATEGIES ADOPTED BY THE RESPONDENTS FOR SEEKING DESIRED INFORMATION (N= 160 EACH)

\begin{tabular}{|c|l|c|c|}
\hline S.No & $\begin{array}{c}\text { Search Strategies Adopted by the } \\
\text { Respondents }\end{array}$ & $\begin{array}{c}\text { Frequency } \\
(\mathbf{\%})\end{array}$ & Rank \\
\hline 1 & OPAC & $90(56.25 \%)$ & 1 \\
\hline 2 & Help from library staff & $80(50.0 \%)$ & 2 \\
\hline 3 & Abstracting journals & $70(43.75 \%)$ & 3 \\
\hline
\end{tabular}




\begin{tabular}{|c|l|c|c|}
\hline 4 & Library Catalogue & $55(34.37 \%)$ & 4 \\
\hline 5 & Access online / Internet Search & $40(25.0 \%)$ & 5 \\
\hline 6 & Others resources & $35(21.87 \%)$ & 6 \\
\hline
\end{tabular}

The respondents have situated all the chase methods as indicated by their importance for their information searching for direct. OPAC search $90(56.25 \%)$ is put from the start position and followed by help from library staff $80(50.0 \%)$ set at the subsequent position, Abstracting journals $70(43.75 \%)$ is put at the third position, Library stock $55(34.37 \%)$ and Internet search $40(25.0 \%)$ are put at fifth position ,Other resources 35(21.87) are set at 6th position. The most standard glancing through direct of the school library customers which is followed by OPAC search.

TABLE 11

RANKING OF THE PREFERRED OF READING MATERIALS (N= 160 EACH)

\begin{tabular}{|c|l|c|c|}
\hline S.No & Preference of Reading Materials & Frequency (\%) & Rank \\
\hline 1 & Text books & $90(56.25 \%)$ & 1 \\
\hline 2 & Reference books & $87(54.37 \%)$ & 2 \\
\hline 3 & Newspaper & $85(53.12 \%)$ & 3 \\
\hline 4 & Magazines & $75(46.87 \%)$ & 4 \\
\hline 5 & Journals & $53(33.12 \%)$ & 5 \\
\hline 6 & Dissertation & $44(27.50 \%)$ & 6 \\
\hline 7 & E-Resources & $42(26.25 \%)$ & 7 \\
\hline 8 & CD/ DVD Databases & $12(7.5 \%)$ & 8 \\
\hline 9 & Others & $10(6.25 \%)$ & 9 \\
\hline
\end{tabular}

out of 160 respondents $90(56.25 \%)$ supported course readings put from the outset position which is followed by Reference books $87(54.37 \%)$ is set at the subsequent position ,News paper $85(53.12 \%)$ is put at the third position, Magazines $75(46.87 \%)$ is put at the fourth position, Journals $53(33.12 \%)$ is put at the fifth position, Dissertation44 (27.50\%) is set at the 6th position, E-Resources $42(26.25 \%)$ is set at the seventh position, CD/DVD Databases 12 (7.5\%) is set at the eighth position, Other resources $10(6.25 \%)$ is put at the 10th position. Most of the customers supported scrutinizing materials for Text book sources.

TABLE 12

SUGGESTION IMPROVE LIBRARY SERVICES AND USAGE (N=160 EACH)

\begin{tabular}{|c|c|c|c|}
\hline S.No & Suggestions & Frequency (\%) & Rank \\
\hline 1 & Develop Adequate Collection of Reading Materials & $85(53.12 \%)$ & 1 \\
\hline 2 & To Organised E-resources/ Internet Training Program & $45(28.12 \%)$ & 2 \\
\hline 3 & Faster Internet services & $20(12.5 \%)$ & 3 \\
\hline 4 & Ensure Regular Power Supply/ UPS Backup & $10(6.25 \%)$ & 4 \\
\hline
\end{tabular}

For each thought the respondents were drawn nearer to rank their appraisal from 1 to 4 situations as indicated by their understanding. The thoughts put sent by the respondents with positions have been ordered and showed up in Table No12, which uncovers that a large portion of the respondent $85(53.12 \%)$ prescribes to cultivate agreeable collection of examining materials is put from the outset position which is followed by facilitated e-resources/Internet Training Program by the College Library $45(28.12 \%)$ and set at the second position however speedier Internet organizations $20(12.5 \%)$, standard power supply/ups support 10 (6.25\%) Most of the customers thought improve library organization and use for encourage adequate grouping of getting materials.. 


\section{SUGGESTION AND RECOMMENDATION}

From the current assessment doubtlessly library customers are not content with the organizations given by the school library. They are going up against various kinds of issues. To recuperate needed information by the customers, the information go between has to certain social methods to make the system incredible. The followings are relatively few thoughts and recommendations to meet the customer's presumptions which rely upon the current examination and thoughts given by the respondents:

> Library should cultivate acceptable library arrangement keeping in see the information needs of the school library customers. Real norms and rule and courses of action should be illustrated and done for palatable grouping progressions;

$>$ Create care among the library customers concerning the sorts of sources, their importance and an incentive for getting the information;

> Use of non-book materials, CD-ROMs data bases for bibliographical chases should be engaged and improved;

> Library should similarly give care program concerning e-consortium organizations giving by library;

$>$ To maintain up their benefit towards e-resources the school should ensure adequate and relentless nonstop power supply

\section{CONCLUSION}

Information need occurs whenever people end up in conditions that important some sort of data for objective. Information has been introduced in present ICT environment in variety of constructions in various sorts ongoing crazes and headways. From the assessment it is evident that the predominant part customers visit library on ordinary timetable. Neighboring their school library some of them similarly truly prefer to open up to the world library. Bigger piece of them moreover visit library to keep them getting Newspaper. Course perusing, reference book, News paper and online resource are the huge wellsprings of information resource in the library. The course readings or reference books are old grouping and most of such material doesn't meet with their suspicion. Various customers are proposing to purchase in extra on-line journals and e-resources of various distributers. A speedy change in information searching for direct and usage of Internet for On-line access of E-resources have become the critical piece of various information needs.

\section{REFERENCES}

1. Devadason, F.J., \& Pratap, P.L. (1997). Methodology for the identification of information needs and uses of users. IFLA Journal 23 (1): 41-51.

2. Ellis, D. (1993). Modeling the information-seeking patterns of academic researchers: A grounded theory approach. Library Quarterly 63: 469-486.

3. Kakai, J.M., Ikoja-Odongo, R., \& Kigongo-Bukenya, I.M.N. (2004). A study of the information seeking behavior of undergraduate students of Makerere University, Uganda. World Libraries 14 (1) Available:http://www.worlib.org/vol14no1/print/kakai_print.html

4. Kavitha,R and Aravind, S (2021), Information Seeking Behaviour Through Internet Technology in Library Users, Chidambaram Town. Emperor International Journal of Library and Information Technology Research, 1(1), 16-23.

5. Wilson, T.D. (1999). Models in information behavior research. Journal of Documentation 55 (3): 249-270.

6. Maheswari .S, and Aravind .S (2021), Usage of the Internet by the Commerce and Science Students in the Selected Arts \& Science Colleges in Madurai - A Study. Emperor International Journal of Library and Information Technology Research, 1(1), 37-42. 